\title{
Development of waste water Treatment Using Solar Energy
}

\author{
D. N. Kale, A. A. Desai1,A. H. Khan ${ }^{2}$,C. D. Pawar ${ }^{3}$, V. N. Chougule ${ }^{4}$ \\ (Department Of Mechanical Engineering, M.E.S. College Of Engineering, Pune, S.P. Pune University, India)
}

\begin{abstract}
Primary shortages for human society are of fresh water and conventional energy source. Solar still is the most prominent non-conventional method to convert the grey water, brackish water into fresh water using solar which is freely and abundantly available. This paper reports about the performance of the solar still under the climatic conditions of Pune (latitude 18.5N). Solar still with three different samples of waste water (Grey water of shaving, Muddy water and Kitchen waste water) with same capacity were tested for water distillation.The temperature of the produced hot water reached as high as $63^{\circ} \mathrm{C}$, and the average water temperature was about $40^{\circ} \mathrm{C}$. The $\mathrm{pH}$ of distilled condensate was found to be between 6.8-7.2 indicating neutral character. Research on 'Cleantech' is done which is a method of reducing the overall organic load of wastewater. The whole study is to support the design and fabrication of a dynamic solar waste water treatment unit.
\end{abstract}

Keywords: Solar Still, pH Value, Water Waste, Distillation.

\section{Introduction}

The Fresh, clean water is a limited resource. The need for safe, clean drinking water is increasing rapidly. It is estimated that out of $1,62,000$ of 5, 75, 000 Indian villages face the problem of brackish/contaminated water [1]. Occurrences such as droughts limit access to fresh and clean water, meaning people need to take steps to reduce water use and save as much water as possible. In some areas of the world, access to water is limited due to contamination. Waste water is the water that emerges after fresh water is used by human beings for domestic, commercial and industrial use. By and large, it is fresh water that is used for a variety of domestic uses such as bathing, washing \& flushing toilets. Washing involves the washing of utensils used in washing, cooking vegetables and other food items washing hands, bathing, washing clothes. The water that emerges after these uses contains, oils used in cooking, vegetable matter detergents, dirt floors that have been washed, soap used in bathing along with oils/greases washed from the human body. This water is referred to as "Grey Water". Water used to flush toilets to evacuate human excreta is called "Black Water".As per standards by the 'CPHEEO' (Central Public Health Environmental \& Engineering Organization), the water consumption per day per person should be between 135 - 150 litres per day [9]. Also expressed as "liters per capita daily" (lpcd).Our country still uses the bygone methods of water treatments in most of the residential areas. The average estimated usage of a common household which do not have a drainage system is up to 135 liters per person.

The total quantity (No. of residents X 135 litres) comes into a sewage treatment plant (STP) in the premises, this total volume has to be treated. In most of the cases, the actual waste generated exceeds this figure leading to overloading of the STP. This happens routinely because most of the residential complexes do not install water meters, water volume meters and flow measurement devices to keep track of water consumption in the community. Consequently, after the installation of a device the readings are monitored, consumption has been found to be triple or at least double the suggested average freshwater usage.The most widely used process for water purification is Distillation. Solar still distillation is a natural phenomenon on earth. Solar energy heats water in the seas and lakes, and then evaporation takes place. Water vapor condenses in the atmosphere and returns to earth as rainwater. Basin type solar still systems replicate this natural phenomenon on a small scale and are the most common method for solar water distillation. The use of non-conventional energy and a robust working mechanism for waste water treatment is yet to be designed which would not have economical constraints. A solar still was designed and fabricated for the purpose of parametric studies; several parameters were investigated such as the solar intensity, average water temperature inside the unit and the amount of water distilled. The system was simulated using actual deviations of solar intensity and environment temperature during a typical summer day in Pune $\left(18.5204^{\circ} \mathrm{N}\right)$. The unit was mainly a predecessor for a ongoing study of the design of a dynamic solar water distillation unit. 


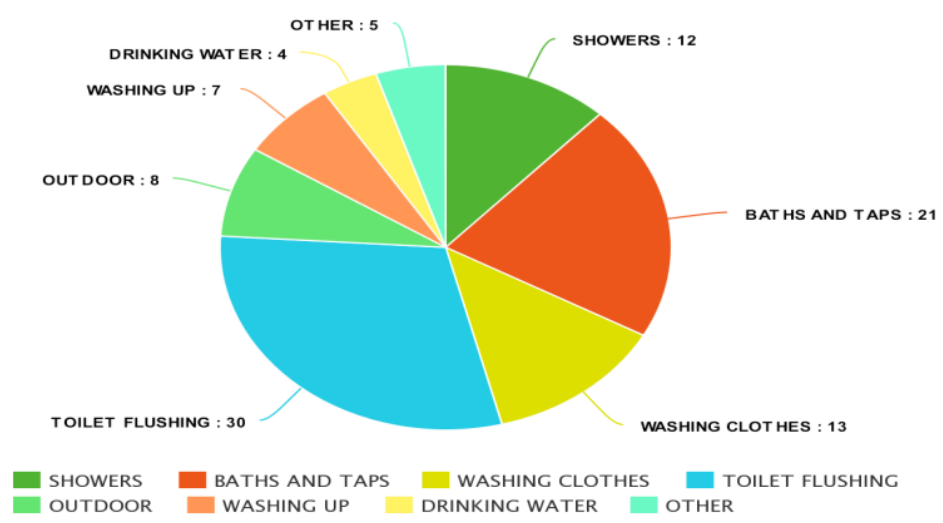

Fig.1 : Average water consumption per household per day (150-135 lpcd)

\section{Experimental setup}

Fig.[2] shows the fabricated Solar still system, which consists mainly of an glass cover and absorber plate which creates a cavity for the condensate to settle. The absorber plate is made of aluminum and is painted to form a black surface (Absorptivity of about 0.95 and emissivity of about 0.07 ). The insulation material used from all sides is wood (Transmissivity of about 0.88). Dimensions of the still are provided in table [1]. The system is inclined at an optimum angle of $30^{\circ} \mathrm{C}$ in order to allow the dripping of condensed water droplets and to insure that at most times of the day the solar rays are normal to the surface. Solar energy warms the absorber plate. The solar still was exposed to solar rays for the time period of $8 \mathrm{hrs}(10 \mathrm{am}-6 \mathrm{pm})$. Initially 1liter of saline water was feed into the still and continuously monitored. The water level before condensation was $2.5 \mathrm{~cm}$. Continuous water level and different temperatures (water temperature \& still temperature) were measured. Thermocouple was used for measuring the temperatures.

Table. 1: Dimensions of the Designed Solar Still

\begin{tabular}{|c|c|}
\hline Specification & Dimension \\
\hline Basin Area & $412.9 \mathrm{~cm}^{2}$ \\
\hline Top Glass Area & $464.51 \mathrm{~cm}^{2}$ \\
\hline Glass Thickness & $4 \mathrm{~mm}$ \\
\hline Aluminum Thickness & $2 \mathrm{~mm}$ \\
\hline Slope Of The Glass & $30^{\circ}$ \\
\hline
\end{tabular}

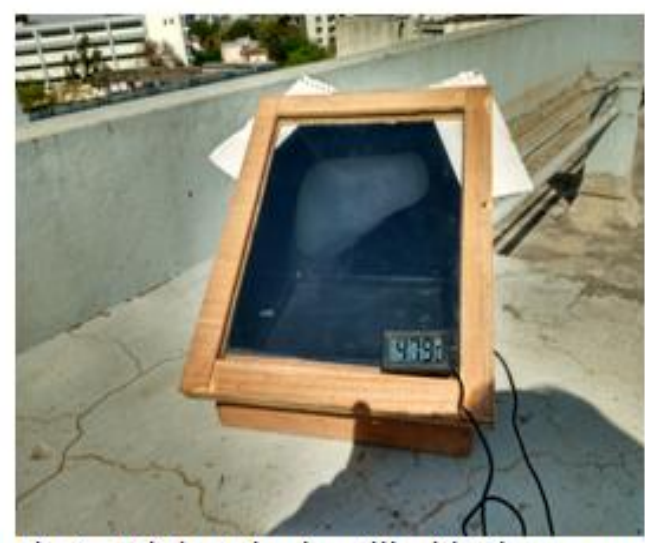

Fig. 2 : Fabricated solar still with Thermocouple

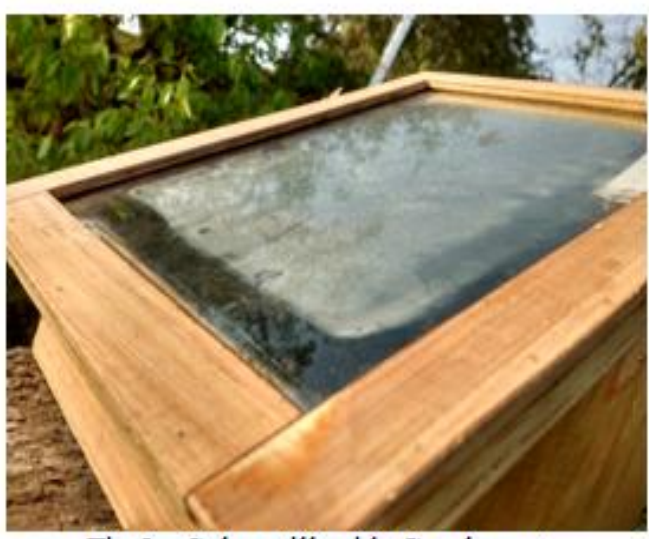

Fig.3 : Solar still with Condensate

\section{Iii. Study of solar radiation}

The radiation from the Sun travels into the space in the form of electromagnetic wave. Above the earth's atmosphere, sunlight carries 1367 watts of power per square meter known as solar constant. The total amount of solar radiation received outside the earth's atmosphere on a unit area perpendicular to the rays of the sun, at the mean distance of the earth from the sun is defined as solar constant. The Earth receives $1.8 \mathrm{x} 1017 \mathrm{~W}$ of solar radiation continuously at top of its atmosphere. Only half of it reaches the surface. Factors like 
scattering, reflection and absorption of light during its passage are responsible for reduction in the amount of solar radiation. By nature, solar energy is a low-density energy source.

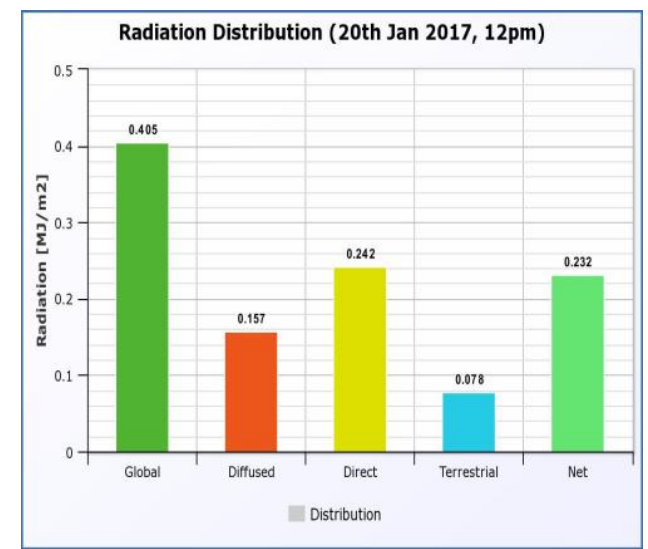

Fig.4: Radiation distribution on $20^{\text {th }}$ Jan 2017

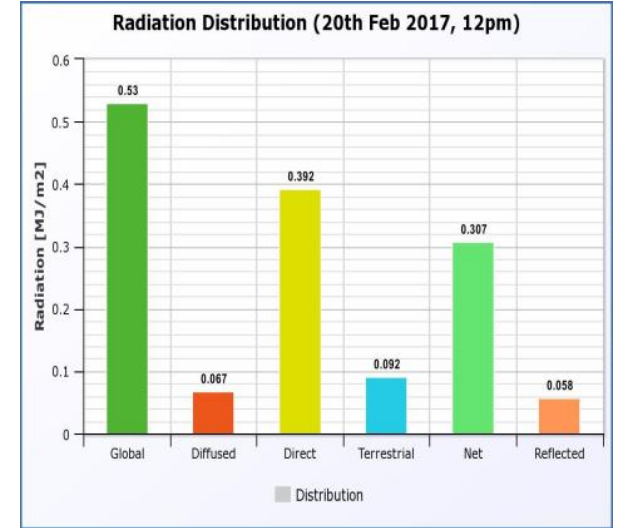

Fig.5: Radiation distribution on $20^{\text {th }} \mathrm{Feb} 2017$

Solar Radiations in Pune were studied for thorough calculations of efficiency and incident solar radiations on the working setup. The tests of the solar still were done in the months of January and February which offered apt readings and a base for our future scope. Based on the parameters of a solar still a dynamic model is being developed. The effects of radiation and the rate of evaporation were the major aspects of the study.

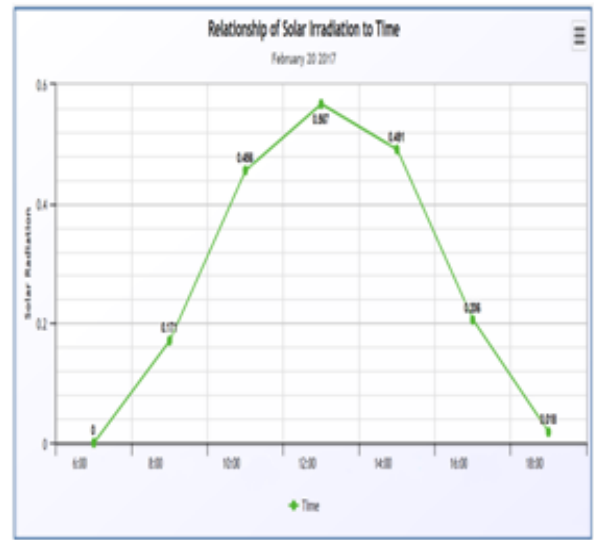

Incident Radiations were recorded from 06:00 am to 06:00 pm in Pune. The Radiations Peaked from 10:00 am to 03:00 pm. Highest recorded reading was at 12:15 $\mathrm{pm}\left(0.567 \mathrm{MJ} / \mathrm{m}^{2}\right)$ The radiations incident on the solar still were completely natural and no accessories were used for the enhancement of the results. Inclusion of Reflectors and fins have shown a rise of over $45 \%-64 \%$ increase in efficiency theoretically [2].

Fig.6: Solar Radiation vs Time (Pune)

\section{Iv. Heat loss calculations for the still}

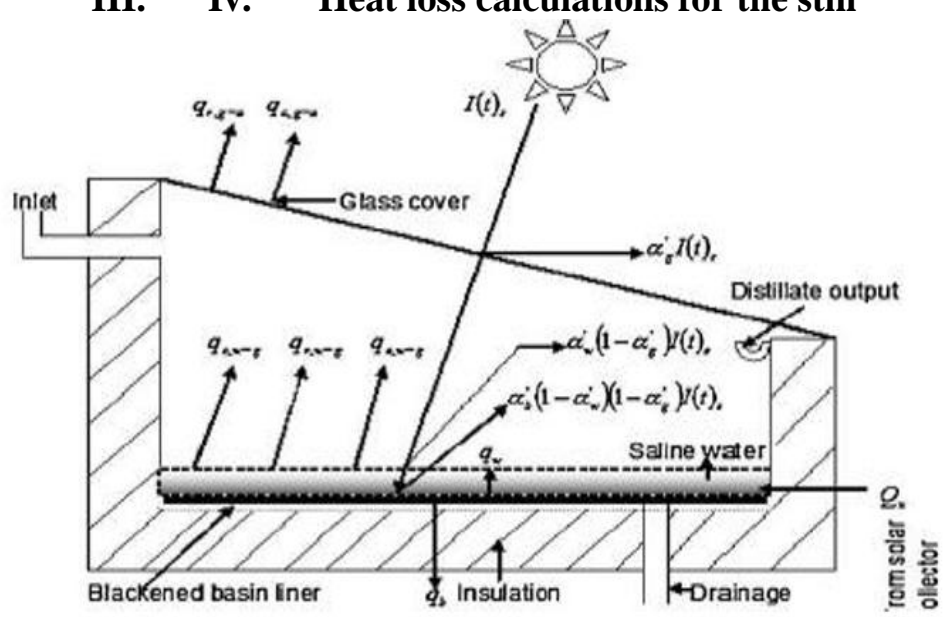

Fig.7: Energy flow diagram of solar still 


\section{Internal Heat Transfer for the Still :}

In solar still internal heat is transferred by convection, evaporation, and radiation. The evaporative and convective transfers take place simultaneously and are independent of radiative heat transfer.

\subsection{Radiative heat transfer:}

The view factor is considered as unity because the glass cover inclination is usually small in the solar still. The rate of radiative heat transfer between glass to water is given by

$\mathrm{q}_{\mathrm{r}, \mathrm{w}-\mathrm{g}}=\mathrm{h}_{\mathrm{r}, \mathrm{w}-\mathrm{g}}\left(\mathrm{T}_{\mathrm{w}}-\mathrm{T}_{\mathrm{g}}\right)$

$\mathrm{h}_{\mathrm{r}, \mathrm{w}-\mathrm{g}}=$ radiative heat transfer coefficient between water to glass

$\mathrm{h}_{\mathrm{r}, \mathrm{w}-\mathrm{g}}=\varepsilon_{\text {eff }} \cdot \sigma\left[\left[\left(\mathrm{T}_{\mathrm{w}}\right)^{2}+\left(\mathrm{T}_{\mathrm{g}}\right)^{2}\right]\left(\mathrm{T}_{\mathrm{w}}+\mathrm{T}_{\mathrm{g}}\right)\right]$

$\varepsilon_{\text {eff }}=$ effective emission between water to glass cover

$\varepsilon_{e f f}=1 /\left[\left(\left(1 / \varepsilon_{\mathrm{g}}\right)+\left(1 / \varepsilon_{\mathrm{w}}\right)\right)-1\right]$

\subsection{Convective heat transfer:}

Natural convection takes place across the humid air inside the basin due to the temperature difference between the inner surface of the glass cover to water surface. The rate of convective heat transfer between water to glass is given by,

$\mathrm{q}_{\mathrm{c}, \mathrm{w}-\mathrm{g}}=\mathrm{h}_{\mathrm{c}, \mathrm{w}-\mathrm{g}}\left(\mathrm{T}_{\mathrm{w}}-\mathrm{T}_{\mathrm{g}}\right)$

$\mathrm{h}_{\mathrm{c}, \mathrm{w}-\mathrm{g}}=$ convective heat transfer coefficient between water to glass

$\mathrm{h}_{\mathrm{c}, \mathrm{w}-\mathrm{g}}=\left[\left(\mathrm{T}_{\mathrm{w}}-\mathrm{T}_{\mathrm{g}}\right)+\left[\left[\left(\mathrm{P}_{\mathrm{w}}-\mathrm{P}_{\mathrm{g}}\right)\left(\mathrm{T}_{\mathrm{w}}\right) /\left[\left(268.9 \times 10^{3}\right)-\left(\mathrm{P}_{\mathrm{w}}\right)\right]\right]\right]\right.$

$\mathrm{P}_{\mathrm{w}}=$ partial vapor pressure at water temperature

$\mathrm{P}_{\mathrm{w}}=\exp \left[25.327-\left(5144 /\left(\mathrm{T}_{\mathrm{w}}\right)\right]\right.$

$\mathrm{P}_{\mathrm{g}}=$ partial vapor pressure at inner surface glass temperature

$\mathrm{P}_{\mathrm{g}}=\exp \left[25.327-\left(5144 /\left(\mathrm{T}_{\mathrm{g}}\right)\right]\right.$

\subsection{Evaporative heat transfer:}

Due to condensation of the water vapor on the glass cover, there is heat loss by evaporation between the glass cover and water surface. This can be expressed as follows.

$\mathrm{q}_{\mathrm{e}, \mathrm{w}-\mathrm{g}}=\mathrm{h}_{\mathrm{e}, \mathrm{w}-\mathrm{g}}\left(\mathrm{T}_{\mathrm{w}}-\mathrm{T}_{\mathrm{g}}\right)$

$\mathrm{h}_{\mathrm{e}, \mathrm{w}-\mathrm{g}}=$ evaporative heat transfer coefficient

$\mathrm{h}_{\mathrm{e}, \mathrm{w}-\mathrm{g}}=\left[16.273 \times 10^{-3} \times\left(\mathrm{P}_{\mathrm{w}}-\mathrm{P}_{\mathrm{g}}\right)\right] /\left(\mathrm{T}_{\mathrm{w}}-\mathrm{T}_{\mathrm{g}}\right.$

\section{Results}

Specimen of Three Types of Waste Water was considered for testing under the grayish and brackish water characteristics. The water was put under study in the months of January and February resulting in the calculations of parameters like Incident Solar Radiations, Dissolved Solids, Suspended Solids and the pH-value of the distilled water. The use of the following readings was to understand the $\mathrm{pH}$ rates and the removal of dissolved or suspended solids. It formed a basis of our research on the behavior of waste water upon distillation. The fabricated unit successfully worked and solar distillation process was successful and capable to produce distilled water. The rate (quantity) of distilled water generated on hourly basis was relatively higher between 12 $\mathrm{pm}$ to 03:00 pm in solar still unit. The distillation rate was decreased thereafter in the unit of solar still due to the increased angle of solar radiation with decreased penetration inside the solar still chamber.

Table. 2: Results for Different Types of Waste Water under Study

\begin{tabular}{|c|c|c|c|c|}
\hline Physico-Chemical Characteristics & \multicolumn{3}{|l|}{ Feed-Water (Before Distillation) } & $\begin{array}{c}\text { Solar Distillate } \\
\text { (After Solar Distillation) }\end{array}$ \\
\hline & $\begin{array}{c}\text { Basin } \\
\text { Water }\end{array}$ & $\begin{array}{c}\text { Kitchen } \\
\text { Water }\end{array}$ & $\begin{array}{c}\text { Muddy } \\
\text { Water }\end{array}$ & \\
\hline pH value & 8.2 & 8.8 & 5.2 & $6.8-7.2$ \\
\hline Total Solids (mg/L) & 923 & 1332 & 1421 & 00 \\
\hline Total Dissolved Solid (mg/L) & 700 & 880 & 316 & 00 \\
\hline Total Suspended Solids (mg/L) & 210 & 452 & 617 & 00 \\
\hline Sulphates (mg/L) & 168 & 254 & 216 & 00 \\
\hline Phosphates (mg/L) & 151 & 176 & 162 & 00 \\
\hline Chlorides (mg/L) & 194 & 233 & 212 & 00 \\
\hline
\end{tabular}


Table. 3: Evaporation Rates of Waste Water under study

\begin{tabular}{|c|c|c|c|}
\hline Sr. No & TIME & $\begin{array}{c}\text { WATER } \\
\text { LEVEL }\end{array}$ & VOLUME \\
\hline 1 & $10 \mathrm{am}$ & $2.5 \mathrm{~cm}$ & $1000 \mathrm{ml}$ \\
\hline 2 & $12 \mathrm{pm}$ & $2.4 \mathrm{~cm}$ & $960 \mathrm{ml}$ \\
\hline 3 & $3 \mathrm{pm}$ & $2.2 \mathrm{~cm}$ & $880 \mathrm{ml}$ \\
\hline 4 & $4: 30 \mathrm{pm}$ & $2.1 \mathrm{~cm}$ & $840 \mathrm{ml}$ \\
\hline 5 & $6 \mathrm{pm}$ & $1.9 \mathrm{~cm}$ & $760 \mathrm{ml}$ \\
\hline
\end{tabular}

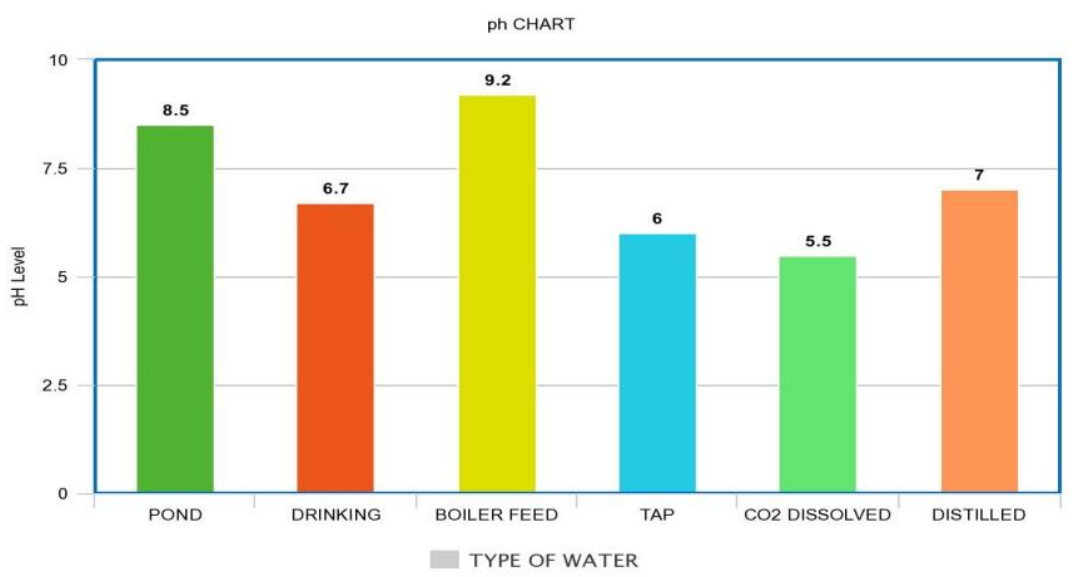

Fig.8: $\mathrm{pH}$ chart for different types of Water

\section{Conclusion}

Several discussions on the solar still are done in this paper. It includes design and fabrication of the solar still system. One of the simple methods to remove salts and other water impurities is the solar still distillation. It is concluded from the distilled water analysis that the water from solar still of any size is pure. The quantity of water distilled is relatively higher in the solar still with high surface area due to higher exposure to solar radiation. Distillation rate will be more if the initial water level will be as low as possible. The productivity of the solar still depends mainly on the surface area of the collector, which is responsible for absorbing both diffused and direct radiation to the maximum possible limit. Also for more efficiency of the solar still system, the thickness of the glass cover should be less, insulation should be well provided from all sides.

This leads to a considerable increase in the evaporative and convective heat transfer coefficients of the solar still.Also pH test was performed in the solar still system with three different waste water samples. Both acidic (below 7) and basic (more than 7) type of samples were taken and after test it was found that the $\mathrm{pH}$ value of samples were $6.8-7.2$, which is neutral character. The TS, TDS, TSS, sulphates, phosphates and chlorides were reduced to zero after the solar distillation in the solar still. It insures that the distilled water. Study on solar radiation pattern in done. This helps in understanding the time period in which the still provides maximum output.

\section{Future scope}

On the basis of throughout study of solar still and solar radiation pattern, we aim on designing and fabricating dynamic solar mechanism for waste water treatment. In today's scenario at most places the sewage waste in directly thrown in the water bodies like river or lake. This includes $99 \%$ of water content. If we pass this sewage through dynamic solar mechanism, we can try to separate out as much water content as possible from the waste. By the use of solar distillation this can be achieved. In such system we will get only dry waste on the other end. The distilled water content after condensation can be reused for various purposes. We can also convert it into drinking water through proper separation of chemicals. Separation of even a small amount of water content will be very helpful as a cumulative result will be comparatively large. 


\section{References}

[1]. S.L.Jadhav, B.L.Chavan and S.S.Patil, Designing, fabrication and performance analysis of solar still for purification of water, Innovative Systems Design and Engineering , ISSN 2222-1727, Vol 2,

[2]. Ajay Kumar Kaviti, Akhilesh Yadav,Amit Shukla, Inclined solar still designs: A review, Department of Mechanical Engineering, Sagar Institute of Science and Technology, Gandhinagar, Bhopal, Madhya Pradesh, India.

[3]. Helmy E Gad, El-Gayar SM, Hisham E Gad. Performance of a solar still with clothes moving wick. Fifteenth international water technology conference.

[4]. Swami Prakash Srivastava, Surat Prakash Srivastava, Solar Energy And Its Role In Indian Economy, International Journal of Environmental Science: Development and Monitoring (IJESDM) ISSN No. 2231-1289, Volume 4 No. 3 (2013).

[5]. Nithin P. K., Hariharan.R, Design and Heat Loss Calculations from Double Effect Type Solar Still Integrated with LFPC,

[6]. Department of ME, LBS College of Engineering, Kasaragod, India.

[7]. G.N Tiwari and Sangeetha Suneja, Performance Evaluation of an inverted absorber solar still, Energy convers Mgmt.Vol-39 (1996) pp 173-180.

[8]. G.N Tiwari, A. Kupfermann, Shruti Aggarwal, A new design for a double slope condensing chamber solar still, Desalination 114(1997) 153-164.

[9]. Hikmet S. Aybar, Mathematical modeling of an inclined solar water distillation system, Department of Mechanical Engineering, Eastern Mediterranean University, G. Magosa, North Cyprus, Mersin 10 Turkey

[10]. Solar Radiation Hand Book (2008), A joint Project of Solar Energy Centre, MNRE Indian Metrological Department

[11]. S. P. Sukhatme, Solar Energy: Principles of Thermal Collection and Storage. 